\title{
MELACAK PENYEBAB AGRESIVITAS VERBAL DI MEDIA SOSIAL BERDASARKAN PERSPEKTIF KAJIAN COMMUNIBIOLOGY
}

\author{
Dewanto Putra Fajar \\ Universitas Brawijaya \\ dewanto.pf@ub.ac.id
}

Received: 31 March 2020 ～Reviewed: 30 June 2020 | Accepted: 15 July 2020

\begin{abstract}
ABSTRAK
Agresivitas verbal di media sosial menjadi permasalahan yang relatif penting saat ini. Hal itu ditunjukkan dengan penggunaan kata-kata, ujaran verbal, yang umumnya diwujudakan menggunakan bahasa dengan konotasi negatif, yang ditujuan untuk menyerang orang lain (pengguna lainnya). Artikel ini bertujuan mendapatkan gambaran holistik pada penyebab munculnya agresivitas verbal di media sosial beradsarkan kajian communibiology, dengan harapan bisa mendapatkan solusi efektif untuk mengurangi agresivitas verbal di media sosial. Lebih lanjut, artikel ini menggunakan pendekatan metodologis berupa kajian literatur (literature review) untuk menjelaskan fenomena agresivitas verbal yang umum terjadi di media sosial. Kajian communibiology menuntun peneliti mendapatkan gambaran besar bahwa sebagian besar agresivitas verbal di media sosial berkaitan dengan mekanisme fisiologis dalam otak, yang berkaitan dengan kepribadian dan pengendalian diri. Pada akhirnya, artikel ini menyarankan bahwa pengendalikan diri merupakan cara efektif untuk menekan kemungkinan penggunaan komunikasi yang buruk, dan agresivitas verbal di media sosial
\end{abstract}

Kata Kunci: Agresivitas Verbal, Media Sosial, Bahasa, Komunikasi, Communibiology

Korespondensi:

Universitas Brawijaya

Jl. Veteran, Ketawanggede, Kecamatan.

Lowokwaru, Kota Malang, Jawa Timur

E-mail: dewanto.pf@ub.ac.id 


\begin{abstract}
Verbal aggressiveness on social media is a relatively important problem today. This is indicated by the use of words, verbal utterances, which are generally manifested using language with negative connotations, which are intended to attack other people (other users). This article aims to get a holistic picture on the causes of the emergence of verbal aggressiveness on social media based on the study of communibiology, with the hope of getting effective solutions to reduce verbal aggressiveness on social media. Furthermore, this article uses a methodological approach in the form of a literature review to explain the phenomenona of verbal aggressiveness that is common in social media. Communibiology studies lead researchers to get the big picture that most verbal aggressiveness on social media is related to physiological mechanisms in the brain, which are related to personality traits and self-control. Finally, this article suggests that self-control is an effective way to reduce the possibility of using poor communication, and verbal aggressiveness on social media
\end{abstract}

Keywords: Verbal Aggressivness, Social Media, Languange, Communication, Communibiology

\title{
PENDAHULUAN
}

Agresivitas verbal menjadi permasalahan penting, karena ia lebih sering muncul dalam interkasi di internet atau media sosial, sebagai cara untuk menyerang pihak kehormatan dan identitas pihak lain, sebagaimana dijelaskan oleh Dean Hample (2008, h 5253). Keadaan demikian menunjukkan bahwa agresivitas verbal merupakan keniscayaan, karena ia berkaitan dengan kemampuan manusia berbicara, berbahasa, dan berkomunikasi. Sayangnya kemampuan komunikasi tersebut tidak hanya digunakan untuk menyampaikan pesan-pesan positif, tapi juga pesan-pesan dengan tujuan negatif, yang pada akhirnya memunculkan agresivitas verbal. Menariknya, agresivitas verbal kemungkinan besar lebih banyak muncul dalam interaksi sosial di dunia maya-menggunakan internet atau media sosial. Hal itu bisa jadi berkaitan dengan sifat umum dari internet yang cenderung melindungi identitas pengguna melalui konsep anonimitas, sebagaimana dijelaskan oleh Sherry Turkle.

Turkle (1997) menyatakan bahwa seseorang bisa menjadi apapun dan siapapun di dalam internet (Lengel, 2009, h 546). Penyataan demikian seakan menegaskan bahwa semua orang bisa melakukan apapun di dalam internet, sekaligus membangun alter ego yang menutupi identitas asli individu, dengan demikian individu secara bebas bisa melakukan agresivitas verbal. Permasalahan munculnya agresivitas verbal di media sosial membuka realitas bahwa mayoritas individu menggunakan perlindungan anonimitas untuk menunjukkan jati dirinya 
sebenarnya sebagai bentuk katarsis (pelampiasan). Hal itu tampaknya mirip dengan penjelasan teori dramaturgi bahwa individu merespon kondisi lingkungannya dengan tindakan tertentu (German, 2009, h 320), karena itu kajian tentang agresivitas verbal menjadi bahasan yang relatif menarik, jika diamati melalui kajian communibiology.

Pembahasan tentang agresivitas verbal selama ini umumnya lebih sering bertumpu pada kajian komunikasi semata, seperti yang dijelaskan oleh Jurgen Grimm. Grimm (2008, h 1907) menjelaskan bahwa perilaku agresif, termasuk juga agresivitas verbal menjadi perilaku frustasi yang muncul dari interaksi sosial individu dengan lingkungannya. Hal itu kemungkinan besar menjadikan mayoritas ahli hanya memfokuskan kajian tentang agresivitas verbal sebagai bagian dari kajian komunikasi semata. Padahal, ilmuwan seperti Sigmund Freud cenderung menjelaskan bahwa agresivitas — termasuk juga agresivitas verbal-cenderung berkaitan dengan frustasi (Grimm, 2008, h 1907), yang notabene bekaitan erat dengan kajian psikologis dan khususnya communibiology. Keadaan demikian menunjukkan keterikatan pada pada tiga konsep utama, yaitu, frutasi dan tekanan lingkungan, agresivitas termasuk juga agresivitas verbal, dan kajian tentang communibiology, yang mengkaji perilaku individu berdasarkan aspek biologis.

Michael J. Beatty dan James C. McCroskey, pencetus kajian communibiology, menunjukkan fakta bahwa perubahan kondisi biologis bisa mempengaruhi perilaku sosial (Beatty, 2008, h 586) - termasuk juga memunculkan agresivitas verbal. Dengan demikian, ada relevansi jelas antara agresivitas verbal, sebagai proyeksi dari perubahan emosional, dengan perubahan konfigurasi kondisi biologis yang terjadi dalam otak dan tubuh manusia. Sayangnya, kajian tentang keterkaitan agresivitas verbal, dan communibiology, masih relatif sedikit ditemui. Lebih jauh, sebagai bagian dari aktivitas sosial, agresivitas verbal umumnya menggunakan bahasa sebagai medianya. Keberadaan bahasa menunjukkan bahwa memiliki kemampuan unik yang membedakan manusia dengan hewan (Bear, Connors, dan Paradiso, $\mathrm{h}$ 2013). Fakta demikian juga menunjukkan bahwa bahasa tidak hanya hadir sebagai hasil dari proses sosial, tapi juga hasil dari proses-proses biologis.

Penelitian Marc D. Hauser, et al (2014, h 5) menemukan fakta penting bahwa kemampuan berbahasa kemungkinan berkorelasi positif dengan perkembangan antomi 
tubuh—-terkait dengan aspek vokalisasi atau pembentukan ujaran—sebagaimana ditunjukkan oleh catatan fosil di spesies $H$. neanderthalensis. Di samping itu, Hauser dan koleganya secara tidak langsung menemukan korelasi bahasa tidak hanya dengan anatomi tubuh, tapi juga dengan kondisi genetik, dan perkembangan otak (Hauser, et al, 2014, h 5). Keadaan demikian menunjukkan bahwa bahasa ialah hasil proses fisiologis dalam otak manusia, yang melibatkan banyak mekanisme rumit yang saling berkaitan. Kenyataan demikian menunjukkan bahwa bahasa-bahasa yang digunakan sebagai media agresivitas verbal, kemungkinan besar merupakan hasil pengolahan informasi dalam otak manusia ketika menanggapi sejumlah besar informasi dari lingkungan - khususnya dari internet atau media sosial. Artikel ini berusaha menguraikan dan mendiskripsikan semaksimal mungkin tentang penyebab munculnya agresivitas verbal di media sosial berdasarkan perspektif communibiology, yang notabene lebih banyak bertumpu proses-proses biologis dalam tubuh manusia. Pada akhirnya, peneliti bisa memberikan solusi untuk menekan dan atau mengurangi kemunculan agresivitas verbal di media sosial.

\section{KAJIAN TEORI}

Kajian communibiology bertumpu pada tiga pengamatan utama, yaitu extraversion, neurotism, dan psychotism, yang semuanya berkaitan dengan mekanisme tubuh manusia menghadapi kondisi lingkungan (Hickson dan Stack, 2010, h 271). Kenyataan demikian menjadi logis, karena semua aktivitas sosial manusia dimulai dari reaksi-reaksi spesifik dalam tubuh, yang semuanya berhubungan dengan mekanisme fisiologis sistem saraf (neurologis), dan sistem hormon (endokrinologis). Hickson dan Stack (2010, h 271) memasukkan perilakuperilaku agresif dan anti sosial ke dalam karegori psychotism, yang bermakna bahwa perilaku agesif tersebut terjadi akibat reaksi-reaksi emosi dalam diri manusia. Pemikiran Hickson dan Stack jelas menguatkan pandangan dari ilmuwan-ilmuwan sebelumnya seperti Freud, yang menjelaskan bahwa agresivitas berhubungan dengan kondisi emosi, dan perasaan frustasi.

Pada awalnya, perubahan kondisi emosional selalu dihubungkan dengan perubahan kondisi psikologis (Stryker dan Vryan, 2006, h 14), namun kajian mendalam akhir-akhir ini menunjukkan kondisi lain. Penelitian Simon N. Young dan Marco Leyton (2002, h 857) pada tahun 2001 menunjukkan bahwa perubahan kondisi emosional dan suasana hati $(\mathrm{mood})$, 
berhubungan erat dengan kadar serotonin-jenis neurotransmiter atau hormon yang bepengaruh pada perubahan kondisi emosional—dan kadar tryptophan, yang notabene terkait dengan kondisi biologis. Dengan kata lain, perubahan emosional-yang memicu munculnya tindakan agresif - tidak hanya berkaitan dengan perubahan psikologis, tapi juga perubahan kondisi fisiologis dalam tubuh.

Pemikiran dan pandangan sejumlah ilmuwan, termasuk Freud, Hickson dan Stack, serta Young dan Leyton berhasil menemukan kembali tentang hubungan antara perilaku sosial manusia dengan perubahan kondisi internal manusia, yang selama ini diabaikan oleh para ilmuwan sosial, termasuk ilmuwan komunikasi. Padahal ilmuwan-ilmwuan di disiplin ilmu kedokteran dan fisiologis, seperti Walter Cannon, Hans Selye, dan John W. Mason berhasil menanamkan pengetahuan dan prinsip dasar tentang hubungan antara kondisi fisiologis manusia dengan perilaku manusia, berdasarkan interaksi sistem saraf dan sistem hormon (Dougal dan Baum, 2003, h 442). Secara sederhana sistem neurologis manusia merupakan sistem pengendali sistem organ berdasarkan mekanisme kerja sistem saraf.

Sistem saraf terpusat di dua organ utama yaitu otak (cerebra) dan sumsum tulang belakang (spinal cord), yang dikenal sebagai sistem saraf pusat, sedangkan jaringan saraf di seluruh tubuh dikategorikan sebagai sistem saraf tepi (Bear, Connors, dan Paradiso, 2013, h 78). Secara umum sistem saraf mengendalikan mayoritas fungsi organ tubuh manusia, termasuk detak jantung, pernafasan, perncernaan, gerakan motoris, hingga fungsi kognitif dan rasionalitas (Carlson, 2015, h 98-99; 104). Sementara itu sistem endrokrin bertumpu pada dua organ utama dalam otak, yaitu hypothalamus dan kelenjar pituitary, dan sejumlah kelenjarkelenjar hromon lain di seluruh tubuh, misalnya kelenjar tyroid, dan kelenjar adrenal (Parker, 2013, h 126). Kinerja sistem hormon berkaitan dengan pengendalikan aspek fisiologis tubuh seperti, pengaturan gula darah, hingga perubahan kondisi fisiologis yang berkaitan dengan perubahan psikologis, seperti dijelaskan Young dan Leyton (2002).

Menariknya pada beberapa kasus, seperti misalnya pada agresivitas, muncul interaksi spesifik antara sistem saraf dengan sistem endokrin. Hal itu menunjukkan bahwa sebagian dari perilaku manusia - termasuk juga perilaku komunikasi-merupakan hasil interaksi antara sistem saraf dan sistem hormon, sebagaimana dijelaskan oleh Hickson dan Stack, serta Young 
dan Leyton. Pada konteks yang lebih spesifik, otak manusia memiliki peran besar pada pembentukan kemampuan berkomunikasi dan berbahasa. Kemampuan berbahasa umumnya berkaitan dengan dua wilayah penting dalam otak manusia, yaitu pusat bahasa Wernicke, dan pusat bicara Broca. Keduanya memegang peran penting pada kemampuan interpertasi bahasa, dan kemampuan berbicara dan berkomunikasi. Sejumlah temuan penting menunjukkan bahwa kerusakan pada wilayah bicara broca menyebabkan kondisi afasia Broca, yang menjadikan penderitanya tidak bisa melafalkan bahasa lisan (Holland dan Ball, 2003, h 477).

Sementara itu, kerusakan pada wilayah bahasa Wernicke atau dikenal sebagai afasia Wernicke menyebabkan seseorang tidak mampu menginterpretasikan bahasa (Saffran dan Schwartz, 2003, h 610). Kedua bentuk afasia di atas membuktikan secara tidak langsung bahwa bahasa tidak hanya sebagai hasil proses-proses sosial, tapi juga hasil dari mekanisme fisiologi dalam otak. Selain itu, fakta bahwa bahasa merupakan hasil dari proses fisiologis dalam otak menuntun pada pemahaman bahwa agresivitas verbal pasti juga berkaitan dengan aktivitas di wilayah Wernicke dan Broca. Meskipun wilayah Wernicke dan Broca berperan penting pada aspek kebahasaan, namun ada wilayah lain yang terlibat pada pembentukan bahasa dan komunikasi. wilayah bahasa Wernicke, dan wilayah bicara Broca, namun kedua wilayah tersebut berinteraksi secara simultan dengan wilayah-wilayah lain, seperti wilayah kepribadian di prefrontal cortex, dan wilayah assosiasi di parietal lobe.

Sederhananya proses dan kemampuan berbicara dan menggunakan bahasa melibatkan banyak bagian otak, sehingga kemampuan tersebut menunjukkan bahwa bahasa dan komunikasi merupakan hasil dari proses fisiologis rumit dalam otak. Lebih jauh, sebagai satu bagian dari proses fisiologis dalam otak manusia, bahasa ikut serta membangun pemahaman tentang lingkungan sosial manusia. Jika kita mengacu pada pemikiran Freud, bahwa kepribadian manusia memiliki andil besar terhadap perilaku sosial, maka perilaku agresif, termasuk agresivitas verbal melibatkan peran wilayah kepribadian. Freud mengajukan teori tentang struktur kepribadian yang terdiri dari tiga unsur utama, id, ego, dan super ego. Secara lebih detail, id merupakan representasi dan metafora dari naluri-naluri dasar manusia; ego menjadi metafora dari pikiran-pikiran logis; sementara super ego merupakan aturan-aturan dan norma-norma yang terinternalisasi dalam otak manusia. (Ashworth, 2000, h 47). 
Menariknya, ketiga unsur kepribadian tersebut bisa ditemukan di wilayah-wilayah spesifik dalam otak manusia. Secara fisiologis, id atau metafora dari aspek naluriah bisa ditemukan pada wilayah otak bernama hypothalamus, yang secara langsung mengendalikan aspek naluri manusia (Parker, 2013, h 94), seperti keinginan bertahan hidup, berkembang biak, dan sebagainya. Sedangkan wilayah super ego kemungkinan besar berada pada wilayah hippocampus dan amygdala, sebagaimana penjelaskan Steve Parker (2013, h 103) bahwa wilayah itu mengendalikan ingatan dan pengalaman-pengalaman emosional—yang sejatinya berkaitan dengan proses internalisasi nilai dan norma. Menariknya, hypothalamus, hippocampus dan amygdala, berada pada lingkup ruang yang sama, yaitu lymbic system atau dikenal sebagai lymbic association area (Martin 1996, h 15; Tortora dan Derrickson, 2011). Sederhanya penjelasan tersebut menunjukkan bahwa id dan super ego rupanya berasal dari wilayah yang sama, atau setidaknya berdekatan satu dan lainnya.

Sedangkan ego atau representasi dari kesadaran, logika, hingga kepribadian, berada di wilayah bagian depan otak, yang dikenal sebagai frontal lobe, khususnya wilayah prefrontal cortex. Secara fisiologis, wilayah prefrontal cortex bertanggungjawab pada aspek kepribadian, rencana, hingga pikiran logis, dan fungsi-fungsi luhur lainnya (Tortora dan Derrickson, 2013, h 554). Kenyataan tersebut memberikan suatu pengertian baru bahwa ada kaitan erat antara kondisi psikologis dengan kondisi fisiologis, terkait dengan perilaku individu. Dengan demikian, perilaku agresif, termasuk juga agresivitas verbal merupakan interaksi rumit antara bagian-bagian otak, terutama antara wilayah lymbic system sebagai metafora dari id dan super ego, dengan wilayah frontal lobe-prefrontal cortex — sebagai representasi dari ego. Perspektif fisiologis tentang pembentukan bahasa dan prinsip-prinsip fisiologis berdasarkan teori kepribadian Sigmund Freud memberikan penjelasan terhadap kemunculan agresivitas verbal. Pada dasarnya agresivitas verbal muncul sebagai bentuk tanggapan fisiologis tubuh terhadap tekanan lingkungan sosial.

Perubahan dan tekanan lingkungan sosial yang hadir dalam bentuk pesan-pesan kebahasaan diolah oleh otak manusia. Pengolahan pesan-pesan kebahasaan tersebut melibatkan sejumlah wilayah dalam otak manusia, yang berkaitan dengan pengolahan bahasa, hingga yang berkaitan dengan naluri dan kepribadian. Hasil pengolahan tersebut memunculkan sejumlah 
tindakan tertentu, terutama berkaitan dengan perilaku-perilaku agresivitas verbal. Proses pengolahan informasi menjadi tindakan tertentu dijelaskan di diagram 1.

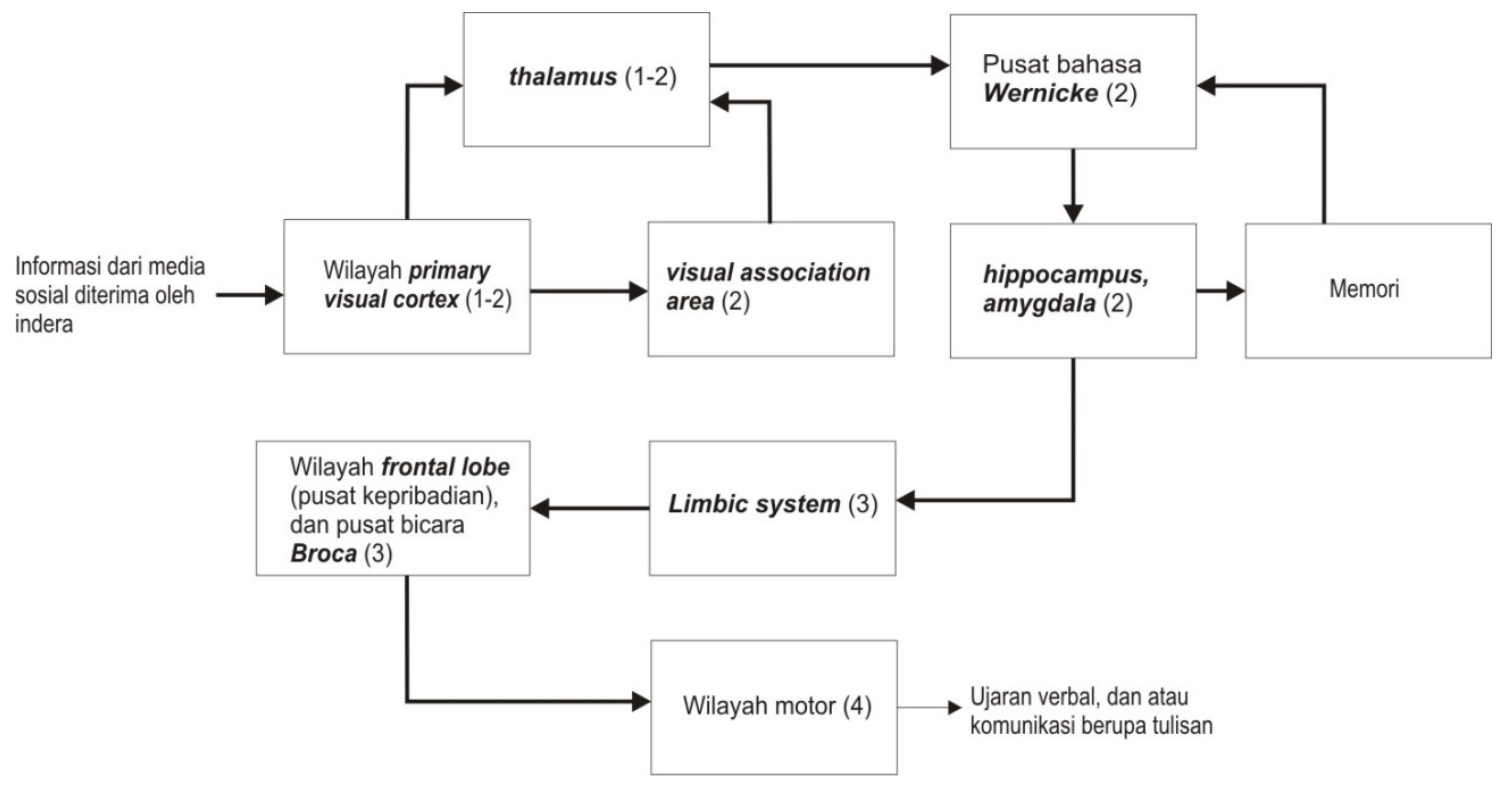

Mekanisme Pengolahan Informasi dalam Otak, terkait dengan Aspek Bahasa Diagram 1 merupakan diagram yang disederhanakan dari proses interaksi rumit dalam proses pengolahan pesan dalam otak manusia, hingga menjadi suatu tindakan tertentu. (Sumber: diolah oleh penulis (2020))

\section{METODE PENELITIAN}

Artikel jurnal ini merupakan artikel rintisan pada kajian communibiology. hal itu menjadikan penulis harus melakukan eksplorasi pada fenomena-fenomena sosial, khususnya fenomena komunikasi, menggunakan perspekif kajian communibiology. Hal itu mengharuskan peneliti melakukan interpertasi terhadap semua data dan fakta yang ditemukan. Hasil interpertasi penulis terhadap semua data dan fakta yang ada memungkinkan penulis membangun diskripsi terhadap fenomena yang terjadi. Secara sederhana, artikel ini merupakan artikel diskriptif dengan pendekatan interpretatif. Eksplorasi, interpertasi, dan diskripsi yang dilakukan memungkinkan penulis menjelaskan fenomena sosial yang ada, yaitu penyebab munculnya agresivitas verbal di media sosial.

Lebih jauh, artikel ini menggunakan pesan-pesan media sosial, seperti komentar dan semacamnya, sebagai obyek penelitian. Proses refleksi dan analisis data yang lebih baik bisa 
diperoleh penulis, karena penulis bisa mendapatkan beragam data baru dari media sosial, jika data yang ada dianggap belum cukup. Sementara itu, penulis memilih dan memilah data dari media sosial secara purposif, dengan cara mengambil semua data, berupa komentar dan sebagainya, dari media sosial, yang dianggap peneliti mengandung agresivitas verbal, serta membuang yang dianggap tidak mengandung agresivitas verbal. Semua data yang berhasil dikumpulkan kemudian direfleksikan dan dianalisis menggunakan pendekatan studi literatur (literature studies).

Penggunaan studi literatur sebagai pendekatan metodologi dilakukan sebagai upaya peneliti mendapatkan penjelasan komprehensif tentang kaitan antara fenomena sosial dengan kajian communibiology. Selain itu, studi literartur merupakan pendekatan yang paling memungkinkan bagi kajian communibiology untuk membangun refleksi dan analisis, selama kajian tersebut memungkinakan penggunaan alat diagnosis bantu-seperti sfigmomanometer, ECG (electrocardiograph), dan EEG (electroencephalograph) — untuk pengumpulan data dan analisis data. Hickson dan Stacks (2014, h 270) juga menjelaskan bahwa penggunaan "pensilkertas" (analisis berdasarkan studi literatur) menjadi analisis pada riset-riset awal communibiology. Pada akhirnya semua data yang diperoleh penulis dianalisis menggunakan tahapan sebagai berikut:

1. Penulis mengumpulkan sebanyak mungkin data dari media sosial yang dianggap mengandung bentuk-bentuk agresivitas verbal, untuk kemudian dilakukan proses refleksi.

2. Proses refleksi peneliti terhadap semua data yang terkumpul dilakukan dengan cara menghubung-hubungkan data dengan pengetahuan peneliti yang diperoleh melalui studi literatur.

3. Hasil proses refleksi selanjutnya akan dianalisis menggunakan perspektif communbiology, yang secara umum terkait aspek fisiologis sistem saraf, dan sebagainya. Proses analisis data dilakukan oleh penulis menggunakan studi literatur untuk mendapatkan penjelasan komprehensif terhadap fenomena yang diamati.

4. Hasil proses analisis digunakan penulis untuk menjelaskan, dan mendiskripsikan temuan penelitian, yang kelak digunakan penulis untuk mendapatkan solusi yang dianggap efektif untuk menekan atau mengurangi agresivitas verbal di media sosial. 


\section{PEMBAHASAN}

Secara umum agresivitas verbal tidak jauh berbeda dengan agresivitas fisik. Keduanya dilakukan untuk menghina, mengolok-olok, dan merendahkan individu lain (Hample, 2008, h 5253). Agresivitas fisik dilakukan dengan sejumlah aktivitas fisik, seperti memukul, menendang, melukai, dan hal-hal lain, serta dilakukan di lingkungan fisik di sekitar kita. Sementara itu, agresivitas verbal muncul bertujuan sama dengan agresivitas fisik, namun menggunakan cara-cara yang berbeda, ranah yang berbeda, serta dampak yang kemungkinan besar bisa lebih parah daripada agresivitas fisik. Menariknya, hampir semua agresivitas fisik selalu berkaitan dengan agresivitas verbal (Spitzberg dan Cupach, 2009, h 456; Dailey, 2007), sedangkan agresivitas verbal tidak selalu berhubungan dengan agresivitas fisik. Hal itu menunjukkan bahwa agresivitas verbal memiliki lingkup lebih luas dan cenderung lebih sering terjadi di ranah sosial manusia.

Agresivitas verbal menggunakan bahasa, intonasi, gestur tubuh atau hal-hal lainnya yang digunakan untuk menyerang individu lain (Hample, 2008, h 5253). Manariknya, agresivitas verbal tidak hanya bisa dilakukan di ranah nyata, tapi lebih sering dilakukan di ranah maya (internet dan media sosial). Lebih jauh, anonimitas di ranah maya menjadikan individu cenderung lebih tidak beretika ketika berkomunikasi, sehingga potensi munculnya agresivitas verbal akan meningkat dibandingkan dengan kondisi di dunia nyata. Keadaan demikian menunjukkan bahwa sifat dan naluri manusiawi, berupa agresivitas verbal, lebih sering ditampilkan dan lebih nyaman disajikan ketika individu dilindungi oleh anonimitas. Bentukbentuk agresivitas verbal bisa ditemukan di beragam media sosial yang ada saat ini, seperti misalnya twitter dan youtube. Sebagian dari bentuk agresivitas verbal ditampilkan menggunakan rangkaian kalimat-kalimat kasar, dan atau umpatan, namun sebagian lainnya menggunakan kalimat dengan konotasi negatif, meskipun tidak menggunakan umpatan.

Apapun istilahnya selama bentuk-bentuk ujaran atau kalimat bertujuan sama, yaitu merendahkan dan menyerang pihak lain, maka hal itu bisa dikategorikan sebagai bentuk agresivitas verbal. Beberapa cuplikan gambar di bawah ini menunjukkan hal tersebut. 

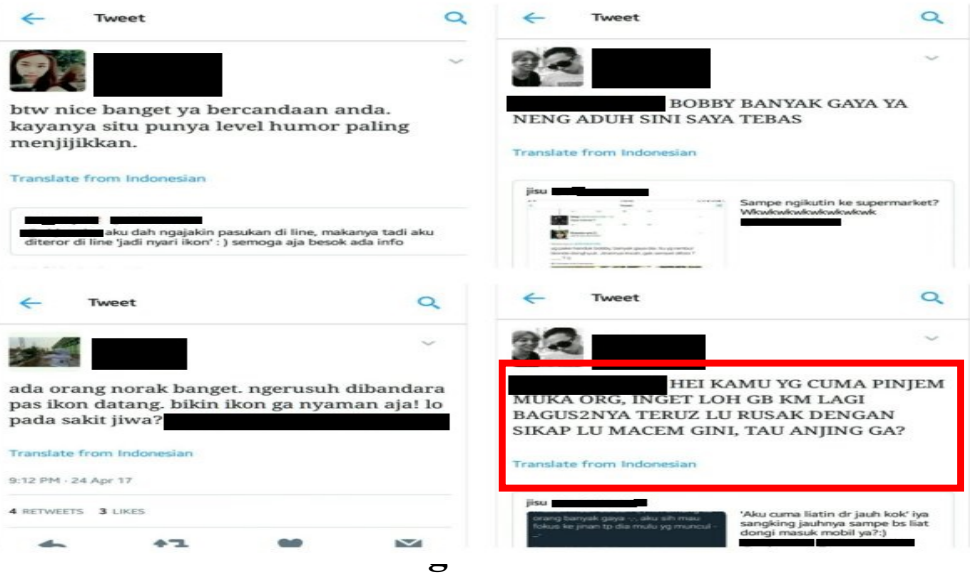

Gambar 1 merupakan sejumlah contoh agresivitas verbal di media sosial Twitter (insert berwarna merah) ditunjukkan dengan penggunaan kosa kata berupa umpatan, atau cacian (2017).

Sumber gambar: https://etikaprofesiteknologiinformasidankomunikasi.wordpress.com/2017/05/18/analisa-kasus/

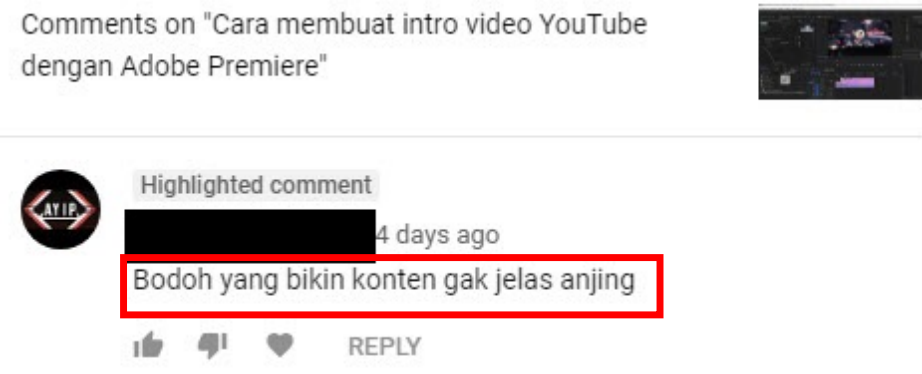

\section{Contoh Bentuk Agresivitas Verbal di YouTube}

Gambar 2 merupakan contoh agresivitas verbal yang muncul di ranah internet dan media sosial, semuanya menunjukkan serangan ke pihak lain atau merendahkan pihak lain (2017) Sumber : http://submitclimb.com/cara-mengatasi-komentar-negatif-di/ youtube/

Cuplikan gambar 1 dan 2 menunjukkan bahwa agresivitas verbal umumnya menggunakan bahasa-bahasa dengan konotasi negatif. Hal itu dilakukan oleh pihak penyerang untuk menghina dan merendahkan pihak yang diserang. Pada gambar 1, seorang netizen memberikan pernyataan kepada akun lain, dengan mengucapkan sumpah serapah, bahkan membandingkan orang lain dengan pernyataan “...TAU ANJING GA?”. Secara harfiah, sejatinya bentuk kalimat yang digunakan menggunakan frase pertanyaan dengan tujuan menanyakan sesuatu. Di sisi lain, jika pertanyaan tersebut dihubungkan dengan kalimat di 
depannya, kemudian diberikan makna konotatif, maka hal itu jelas mengandung bentuk-bentuk agresivitas verbal. Netizen di gambar 1 secara jelas melakukan penghinaan dan penyerangan pada harga diri akun lainnya, dengan pertanyaan retoris bernada hinaan. Seakan-akan netizen tersebut menyamakan orang lain dengan anjing - dalam konteks interaksi sosial penggunaan kata anjing dengan intonasi dan tujuan negatif ialah bentuk penghinaan.

Hal serupa juga dilakukan oleh netizen di gambar 2. Netizen tersebut menyatakan hinaan dengan ungkapan “Bodoh yang bikin konten gak jelas anjing”. Penggunaan kata anjing pada cuplikan gambar 1 dan 2 sejatinya tidak merujuk pada hewan karnivora tertentu, tapi merujuk pada penghinaan terhadap orang lain. Umpatan dan hinaan seperti itu umumnya muncul dalam dua kondisi, pertama, ketika seseorang sedang stress atau frustasi; kedua, ungkapan demikian bisa muncul dalam kondisi normal—ketika individu tidak sedang stress atau frustasi. Pada kondisi pertama ungkapan tersebut muncul karena tekanan emosional akibat stress atau frustasi, sedangkan pada kondisi kedua ungkapan itu kemungkinan besar berkaitan dengan lemahnya pengendalikan diri dan kepribadian individu. Dean Hample (2008, h 5254), dari Universitas Maryland, menyatakan secara khusus bahwa bukti-bukti empiris terkait agresivitas verbal berhubungan langung dengan sifat-sifat manusia dan aspek kepribadian, yang semuanya bermuara pada aspek biologis dalam diri manusia.

Hal demikian menujukkan bahwa mekanisme fisiologis dalam otak manusia menjadi penyumbang paling besar bagi kemunculan perilaku-perilaku agresif, termasuk agresivitas verbal, karena otak ikut serta mengedalikan kepribadian manusia. Sejumlah bukti menujukkan bahwa agresivitas verbal melanda mayoritas pengguna internet dan media sosial, dan mungkin saja hanya sebagian kecil dari pengguna internet dan media sosial yang mungkin tidak melakukan agresivitas verbal, meskipun kesempatan untuk melakukannya terbuka lebar. Keadaan demikian menujukkan bahwa keputusan untuk melakukan agresivitas verbal ditentukan berdasarkan pertimbangan paling logis di dalam otak manusia. Karena itu, semua individu yang melakukan agresivitas verbal memandang bahwa hal itu merupakan pilihan paling logis untuk menyalurkan kebutuhan naluriahnya. sementara individu yang tidak melakukannya kemungkinan besar memandang bahwa agresivitas verbal bukan satu-satunya cara menyalurkan kebutuhan naluriah. Hal demikian menjadikan pemahaman tentang cara kerja otak manusia ketika membangun keputusan menjadi penting. 
Pandangan demikian secara jelas menguatkan pandangan Freud tentang, kaitan antara kepribadian dan aspek biologis. Secara neurologis, kemunculan agresivitas verbal merupakan hasil interaksi rumit antara wilayah kepribdaian di prefrontal cortex dengan wilayah naluri dasar di limbic system, yang disusun oleh hippocampus, amygdala, dan hypothalmus. Sementara itu, wilayah prefrontal cortex - menjadi bagian dari wilayah frontal lobe di bagian depan otak manusia-bertanggungjawab penuh pada pengendalian fungsi-fungsi luhur individu, termasuk diantaranya ialah kepribadian manusia (Sherwood, 2009, h 163-164). Selain itu, pusat bicara Broca juga berlokasi di wilayah frontal lobe, bahkan berdekatan dengan prefrontal cortex — lokasi kepribadian—dan wilayah premotor (Tortora dan Derrickson, 2011, h 553). Fakta demikian, memunculkan kemungkinan menarik bahwa seseorang dengan kepribadian baik, pasti akan mengucapkan hal-hal baik, santun ketika berbicara dan berbahasa, dan selalu berusaha berprilaku baik.

Sebaliknya, seseorang dengan kepribadian buruk umumnya selalu mengucapkan halhal buruk, berbicara dan berbahasa tanpa etika, serta cenderung agresif. Situasi demikian kemungkinan besar menjadi satu bagian yang ikut memunculkan perilaku-perilaku agresif, termasuk dalam hal berbahasa. Lebih lanjut, wilayah prefrontal cortex tidak bekerja secara independen ketika menyusun perilaku, termasuk agresivitas verbal. Prefrontal cortex berhubungan secara simultan dengan limbic system terdiri dari sejumlah sub sistem penting seperti hippocampus, amygdala, dan hypothalamus (Martin, 1996, h 15). Lymbic system dihubungkan dengan sirkuit saraf dengan fungsi saling tumpang tindih untuk mengendalikan efektor otak: motor somatic, neuroendocrine, hingga fungsi-fungsi pengendalian otonom (Martin, 1996, h 448). Hal itu menjadikan limbic system bertanggungjawab pada fungsi-fungsi dasar individu seperti halnya naluri dasar manusia, motivasi, dan emosi (Sherwood, 2009, h 163-164), Secara sederhana, perilaku naluriah yang dikendalikan oleh limbic system muncul sebagai modal dasar individu untuk bertahan hidup menghadapi lingkungan sosial dan lingkungan natural (Parker, 2013, h 94). Keadaan seperti itu menunjukkan bahwa reaksi agresif kemungkinan besar terkait dengan usaha manusia mempertahankan dirinya dari serangan manusia lainnya. Namun pada kasus di atas (gambar 1 dan 2) agresivitas verbal kemungkinan besar muncul dari pikiran-pikiran logis atau kesadaran diri untuk menyerang orang lain. 
Fenomena tersebut kemungkinan besar dipengaruhi sepenuhnya oleh kondisi kepribadian individu.

Sejumlah temuan, pada kasus agresivitas, menunjukkan bahwa tingkat serotonin yang rendah dalam otak rupanya cenderung menjadikan individu lebih mudah berperilaku agresif (Nevid, Rathus, dan Greene, 2005, h 206; Toufexis, 1993). Serotonin sendiri dikenal sebagai jenis neurotransmitter dalam otak manusia yang memiliki kemampuan untuk menurunkan kecenderungan agresivitas individu (Nevid, Rathus, dan Greene, 2005, h 206). Kondisi demikian menunjukkan secara umum bahwa individu dengan tingkat serotonin normal cenderung lebih tenang dibandingkan individu dengantingkat serotonin lebih rendah. Temuan Nevid, Rathus, dan Greene secara jelas menguatkan temuan penelitian Young dan Leyton (2002) Dengan demikian perilaku-perilaku manusia tidak dibentuk oleh satu bagian otak semata, tetapi dihasilkan melalui interaksi rumit antara wilayah prefrontal cortex dengan limbic system, serta interaksi neurotransmitter-seperti serotonin-dengan wilayah-wilayah otak tertentu, yang secara langsung mendukung teori unsur-unsur kepribadian Freud.

Kerumitan proses pengolahan dan pembentukan bahasa, serta kemampuan berbicara menunjukkan bahwa semua bentuk ujaran verbal (lisan dan tulisan) merupakan representasi individu tersebut, atau setidaknya kepribadian individu tersebut. Proses penggunaan bahasa untuk agresivitas verbal pasti melibatkan interaksi antara wilayah bahasa Wernicke dan pusat bicara Broca. Akan tetapi, keputusan akhir terkait munculnya agresivitas verbal atau tindakan non agresif diputuskan di frontal lobe, khsusunya wilayah prefrontal cortex, berdasarkan beragam pertimbangan, selain juga pengaruh kepribadian individu. Kepribadian menjadi faktor penting, karena ia ikut menentukan sikap, perilaku, dan tindakan seseorang, khususnya ketika berkomunikasi, termasuk komunikasi menggunakan internet dan media sosial. Sederhananya, aktivitas di prefrontal cortex, memberikan individu variasi alasan dan tujuan terkait perilaku tertentu. Secara sederhana, wilayah kepribadian layaknya hard ware yang diisi dengan sejumlah soft ware tertentu yang secara aktif mengendalikan kerja hard ware tersebut. Jika semua yang diisikan dalam kepribadian ialah sesuatu yang baik, maka kepribadian mendorong munculnya sikap dan perilaku baik. Di sisi lain, jika kepribadian diisi dengan beragam hal buruk, maka sikap dan perilaku manusia cenderung pada keburukan. Diagram 2 di bawah ini 
menyederhanakan kondisi sebenarnya tentang pembentukan perilaku berdasarkan pengaruh kepribadian.

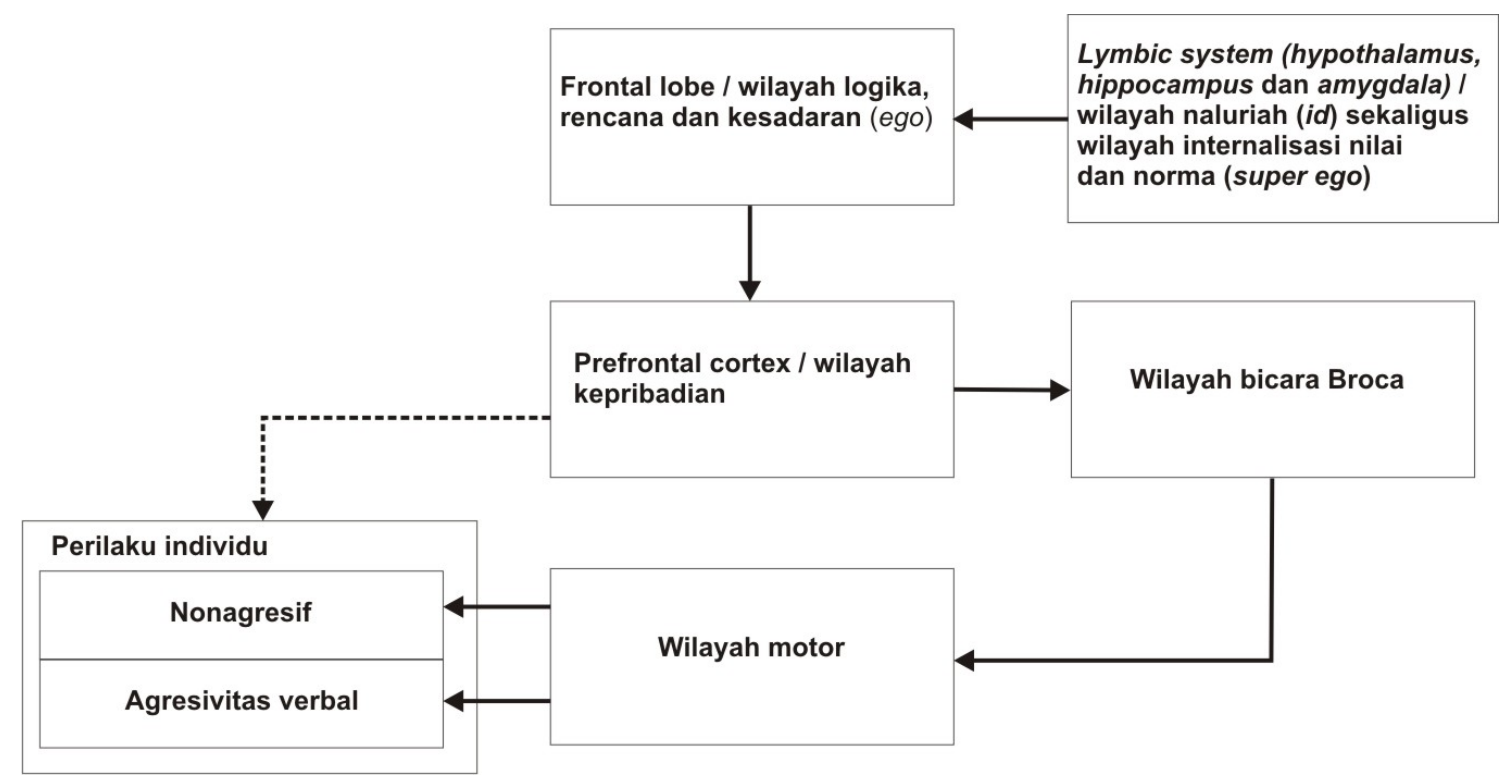

\section{Pembentukan Perilaku Berdasarkan Unsur Kepribadian}

Diagram 2 merupakan mekanisme yang disederhanakan tentang proses yang terjadi dalam wilayah prefrontal cortex terkait dengan peran kepribadian manusia ketika membangun suatu tindakan tertentu, khusunya pada tindakan agresivitas verbal.

(Sumber: Diolah oleh penulis (2020))

Diagram 2 di atas menjelaskan bahwa wilayah kepribadian di prefrontal cortex dipengaruhi oleh wilayah-wilayah tertentu dalam otak manusia. Hal demikian menunjukkan bahwa wilayah kepribadian bukan wilayah independen yang berdiri sendiri, namun wilayah aktif yang mengolah beragam informasi yang diterima. Kondisi demikian menunjukkan bahwa keprbadian bukan sesuatu yang statis, melainkan sesuatu yang dinamis dan bisa berubah sepanjang kehidupan manusia. Karena itu, ada kemungkinan bahwa trauma atau cedera kepala di wilayah frontal lobe, khususnya prefrontal cortex kemungkinan besar bisa mengubah kepribadian dan perilaku manusia.

Karena itu ada kemungkinan bahwa agresivitas individu terhadap individu lain bisa jadi merupakan hasil dari agresivitas atau kekerasan yang diterima selama masa tertentu. 
Sedangkan, pendidikan moral yang sangat intensif, konsisten, dan berkesinambungan berpotensu mampu mengubah kepribadian manusia menjadi lebih santun, tunduk dan patuh. Pada akhirnya, kita bisa menemukan benang merah antara agresivitas verbal dengan kepribadian manusia, meskipun pada dasarnya kita tidak benar-benar mampu menjelaskan alasan logis penyebab munculnya agresivitas atau perilaku nonagresif, termasuk munculnya agresivitas verbal, karena semuanya merupakan pilihan pada masing-masing individu.

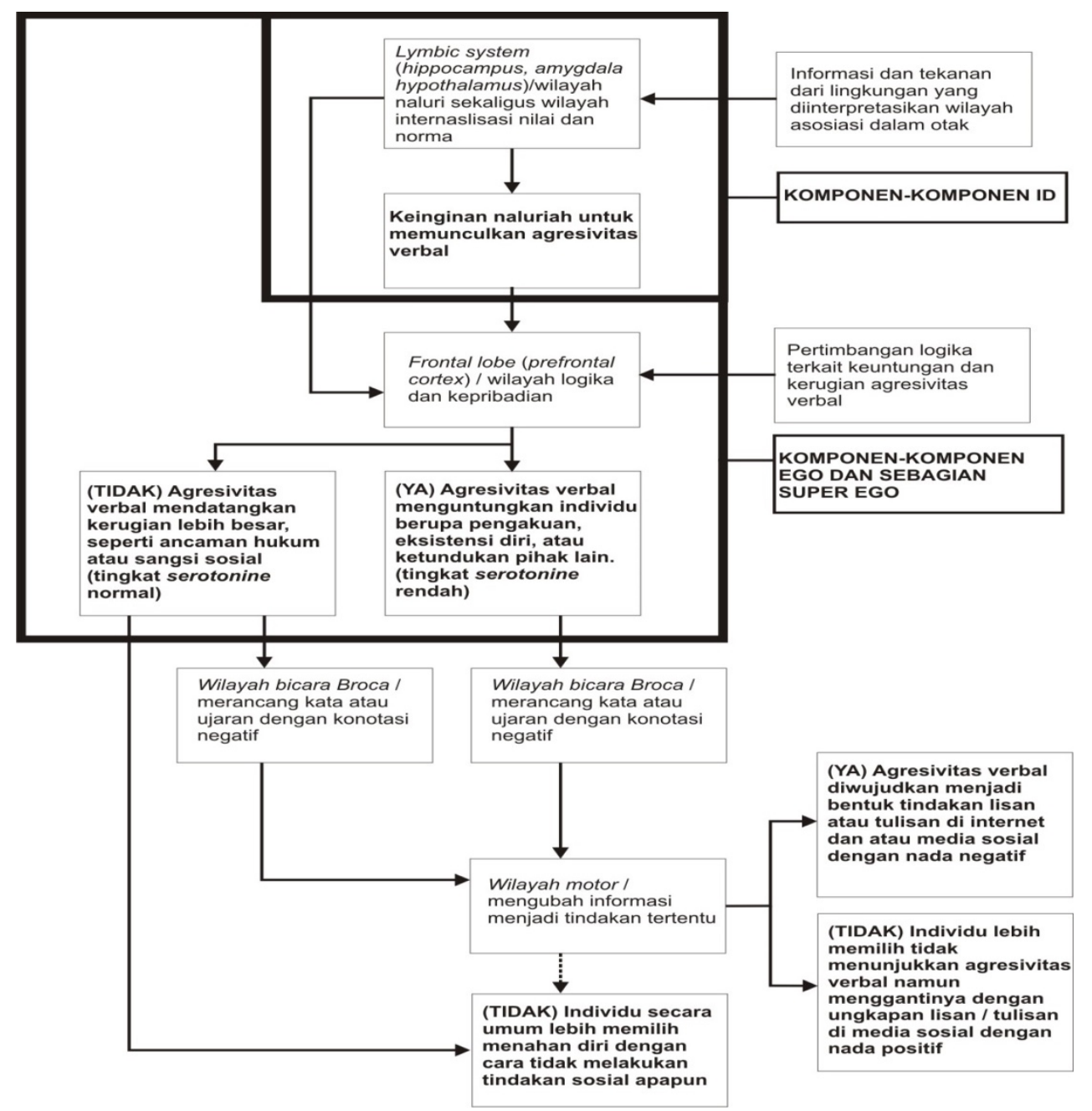

Diagram alir pembuatan keputusan agresif atau nonagresif

Diagram 3 merupakan diagram alir tentang mekanisme pembentukan keputusan terkait dengan kepribadian dan pertimbangan logis tentang pembuatan keputusan untuk perilaku agresif dan atau nonagresif, khususnya terkait dengan agresivitas.

(Sumber: Diolah oleh penulis (2020)) 
Pengambilan keputusan tentang perilaku agesif atau perilaku nonagresif dalam aspek verbal, seperti dijelasan dalam diagram di atas, melibatkan sejumlah pertimbangan logis di tiap-tiap diri individu. Sementara itu wilayah kepribadian memberikan dukungan atau penolakan pada tindakan tertentu, karena itu secara mendasan perilaku agresif atau non agresif merupakan pilihan bagi masing-masing individu, sehingga dalam situasi tertentu agresivitas bukan sepenuhnya tindakan naluriah. Jika kita analisis sejumlah posting dan komentar di media sosial (gambar 1 dan 2), maka kita bisa menemukan sejumlah fakta penting yaitu, pertama, semua komentar negatif umumnya ditujuan kepada individu lain sebagai bentuk tanggapan terhadap informasi yang diterima; kedua, kebanyakan pelaku agresivitas verbal tidak sepenuhnya mampu untuk mengendalikan perilaku agresifnya sebagai bagian dari keinginan naluriahnya; ketiga, perilaku-perilaku agresif demikian muncul di ranah internet dan media sosial, karena perlindungan anonimitas, bahkan sebagian besar pelaku agresivitas verbal menggunakan nama samara atau alias.

Semua fakta di atas menunjukkan bahwa sejatinya individu memiliki kesempatan untuk mengendalikan semua perilaku yang dihasilkan. Sayangnya, proses pengendalian terhadap perilaku menjadi luntur akibat sejumlah fungsi di dalam internet, seperti fungsi anonimitas. Keadaan demikian menjadikan peran dan fungsi naluriah individu menjadi lebih dominan dibandingkan peran dan fungsi logika, hal demikian menunjukkan bahwa naluri individu seakan-akan mengatakan "kau tenang saja, kita akan aman mengatakan apapun di internet, karena tidak ada yang tahu siapa kita sebenarnya." Karena itu, kemampuan individu mengendalikan diri menggunakan pertimbangan logis menjadi sarana utama mengurangi munculnya agresivitas verbal di internet dan atau media sosial.

\section{KESIMPULAN}

Penjabaran pada pembahasan menemukan fakta penting bahwa agresivitas verbal di media sosial muncul karena tiga aspek besar. Pertama, agresivitas verbal muncul sebagai bentuk tanggapan terhadap informasi dari media sosial. Jika informasi dari media sosial memiliki kecenderungan pada pesan-pesan negatif, maka individu akan memberikan tanggapan negatif pula. Sedangkan jika informasi dari media sosial tidak mengandung unsur- 
unsur negatif, maka tanggapan individu berupa agresivitas verbal kemungkinan besar berkaitan interpretasi individu dan kondisi kepribadian masing-masing individu.

Kedua, agresivitas verbal di media sosial berkaitan merupakan hasil dari kepribadian masing-masing individu, atau hasil dari interaksi unsur-unsur kepribadian (id, ego, super ego) yang menjadi metafora dari interaksi antara lymbic system (id dan super ego) dengan prefrontal cortex (ego). Ketiga, penggunaan bahasa-bahasa negatif dalam agresivitas verbal pada hakekatnya dipengaruhi oleh interaksi kepribadian dengan wilayah-wilayah pengendali bahasa di dalam otak manusia, khususnya pada pusat bicara Broca, yang secara anatomis berdekatan dengan wilayah kepribadian manusia (prefrontal cortex). Ketiga aspek tersebut kemungkinan tidak berlaku secara umum pada semua pengguna media sosial, karena perbedaan kondisi kepribadian dan kondisi fisiologis di dalam otak. Hal demikian menjadikan sebagian pengguna media sosial cenderung sering melakukan agresivitas verbal, sementara sebagian lainnya tidak memilih tidak melakukan agresivitas verbal.

Berdasarkan kesimpulan di atas, penulis mengajukan dua solusi untuk menekan atau mengurangi potensi perilaku agresivitas verbal di media sosial, berdasarkan kajian communibiology. Pertama, pengguna media sosial harus mampu menahan diri untuk tidak melakukan agresivitas verbal, dengan berpikir logis tentang manfaat dan mudharat dari hal itu. Pada dasarnya, otak manusia merupakan organ yang sangat dinamis merespon perubahan lingkungan, sehingga usaha untuk menahan diri dari perilaku agresivitas verbal menjadikan otak terbiasa pada aktivitas tersebut. Pembiasaan tersebut, pada akhirnya mendorong individu untuk berperilaku baik (nonagresif).

Kedua, seperti halnya otak manusia, kepribadian manusia juga bersifat dinamis, sehingga berubah sesuai dengan ragam informasi yang masuk. Menariknya kepribadian mendorong munculnya beragam perilaku sosial, termasuk komunikasi, dan juga agresivitas verbal. Dengan demikian, pemilihan dan pemilahan informasi-informasi yang baik dan bermanfaat berpotensi besar mengubah kepribadian manusia menjadi lebih baik, sehingga menuntun pada perilakuperilaku yang baik pula. Sederhananya, kepribadian yang baik membantu mengurangi dan menekan munculnya perilaku agresivitas verbal di semua ranah, secara khusus di ranah media sosial. 


\section{DAFTAR PUSTAKA}

Ashworth, P. (2000). Psychology and 'Human Nature'. Philadelphia: Psychology Press.

Bear, M. F. Connors, B. W. Paradiso, M. A. (2016). Neuroscience Exploring The Brain. Fourth edition. Philadelphia: Wolters Kluwers.

Carlson, N. R. (2015). Fisiologi Perilaku, edisi kesebelas, jilid 1. Damaring Tyas Wulandari (terj). Jakarta: Penerbit Erlangga.

Beatty, M. J. (2008). Communibiology. dalam Wolfgang Donsbach (editor) International Encyclopedia of Communication: 595-591. Malden: Blackwell Publishing.

Dougall, A. L. Baum, A. (2003). Stress, Coping, and Immune Function. dalam Michela Gallagher dan Randy J. Nelson (editor) Handbook of Psychology, Volume 3, Biological Psychology. 441-455. New Jersey: John Wiley \& Sons, Inc.

Grimm, J. (2008). Frustation Aggression Theory. dalam Wolfgang Donsbach (editor) International Encyclopedia of Communication: 1907-1909. Malden: Blackwell Publishing.

Hample, D. (2008). Verbal Aggressivness. dalam Wolfgang Donsbach (editor) International Encyclopedia of Communication: 5253-5257. Malden: Blackwell Publishing.

Holland, P. C. Ball, G. F. (2003). The Psychology and Ethology of Learning. dalam Michela Gallagher dan Randy J. Nelson (editor) Handbook of Psychology, Volume 3, Biological Psychology. 457-497. New Jersey: John Wiley \& Sons, Inc.

Hauser, M. D. et al. (2014). The mystery of languange evolution. dalam Frontier of Psychology. Vol 5. Article $401: 1-12$.

Hickson, M. Stack, D. W. (2010). Biological Views of Communication, dalam The Review of Communicatiom. Vol 10. No 2: 263-275. London: Routledge 
Lengel, L. (2009). Computer Mediated Communication. dalam William F. Eadie (editor) $21^{s t}$ Century Communication, A Reference Handbook, vol 2 : 543-549. Thousand Oaks: Sage Publication.

Martin, J. H. (1996). Neuroanatomy, Text and Atlas. London: Prentice Hall International.

Nevid, J. S, Rathus, S. A, Greene, B. (2005). Psikologi Abnormal. Jilid 2. Edisi kelima. Jeanette Murad dkk (terj). Jakarta: Penerbit Erlangga.

Parker, S. (2013). Ensiklopedia Tubuh Manusia. Winardini dan Damaring Tyas Wulandari (penerjemah). Jakarta: Erlangga.

Saffran, E. M. Schwartz, M. F. (2003). Language. dalam Michela Gallagher dan Randy J. Nelson (editor) Handbook of Psychology, Volume 3, Biological Psychology. 595-636. New Jersey: John Wiley \& Sons, Inc.

Sherwood, L. (2009). Fisiologi Manusia. edisi keenam. Brahm U. Pendit (terj). Jakarta: Penerbit Buku Kedokteran EGC.

Spitzberg, B, H, Cupach, W, R. (2009). Unwanted Communication, Aggresion, and Abuse. dalam William F. Eadie (editor) $21^{\text {st }}$ Century Communication, Reference Handbook: 454-462. Thousand Oak: Sage Publication.

Stryker, S. Vryan, K. D. (2006). The Symbolic Interactionist Frame. dalam John Delamater (editor) Handbook of Social Psychology: 3-28. New York: Springer.

Tortora, G. J, Derrickson, B. (2011). Principles of Anatomy \& Physiology. (13th edition). vol 1. New Jersey: John Wiley \& Sons.

Young, S. N. Leyton, M. (2002). The role of serotonin in human mood and social interaction Insight from altered tryptophan levels. dalam Pharmacology, Biochemistry, and Behavior. Vol 71: 857-865: Elsevier. 